Гордана Станчић, мастер

Андрићев институт

gordana.nedeljkov06@gmail.com https://doi.org/10.18485/ai_san_o_gradu.2018.ch6

\title{
БИБЛИОТЕКА АНДРИЋЕВОГ ИНСТИТУТА У БИТИ СНА О ГРАДУ
}

Андрићград, идејна творевина Емира Кустурице, „најмлађи стари град“, у славу јединог српског нобеловца, за јавност је отворен 2014. године. Тада је са радом почео и Андрићев институт, научноистраживачка установа основана са циљем да обавља основна, примењена и развојна истраживања од општег интереса за развој националног идентитета, очување богатства културне и историјске баштине и научноистраживачки рад у области историје, књижевности, језика и филма и медија. Андрићев институт организује научне конференције на међународном нивоу, стручне скупове, летње школе, промоције својих издања и издања других издавачких кућа, и развија издавачку делатност.

Библиотека „Иво Андрић“ Андрићевог института основана је са намером и жељом да подржава рад Андрићевог института и квалитетом свога фонда и својих услуга омогући висок квалитет истраживачког рада својим корисницима. У Библиотеци Андрићевог института континуирано се обављају послови набавке и селекције грађе, инвентарисања, смештаја, каталогизације и класификације књига и часописа, као и давања на коришћење научним радницима и студентима током конференција, семинара и летњих школа. Циљ стварања Библиотеке као образовног, информационог и културног центра Андрићграда остварује се редовним стручним усавршавањем запосленог кадра, аутоматизацијом пословања, формирањем референсне збирке и пружањем подршке процесу доживотног учења. 
Кључне речи: Андрићград, Андрићев институт, Библиотека „Иво Андрић“.

\section{1. Андрићград, најмлађи стари град на свету}

Андрићград, идејна творевина Емира Кустурице, „најмлађи стари град“, у славу јединог српског нобеловца, за јавност је отворен 2014. године. Осмишљен као споменик 500 година дугој српској историји, он је уједно и „водич“ кроз књигу На Дрини ћуйрија и омаж српском нобеловцу Иву Андрићу. Андрићград је препун симболике која асоцира на поједине делове српске историје, на значајне историјске моменте, на људе и догађаје. Андрићград, заједно са Андрићевим институтом, постаје културно и образовно средиште источног дела Републике Српске и шире, град у којем се негују културне вредности, промовише културни садржај, град у којем се учи, образује и напредује.

Ипак, овакав град, не би био то што јесте, да у њему не постоји Библиотека, јер без постојања Библиотеке, сан о (идеалном) граду био би непотпун. Оформљена, развијена и функционална библиотека, њени фондови и колекције представљају културно, научно, образовно и информационо језгро свакога града.

\section{2. Андрићев институт}

Андрићев институт је научноистраживачка установа основана са циљем да обавља основна, примењена и развојна истраживања од општег интереса за развој националног идентитета, очување богатства културне и историјске баштине и научноистраживачки рад у 
области историје, књижевности и филма и медија. Андрићев институт своју мисију спроводи кроз деловања својих одељења: Одељења за историју, Одељења за књижевност, Одељења за српски језик, Одељења за филм и медије. Поред наведених одељења, у оквиру Андрићевог института постоје и Галерија „Петар Лубарда“ и Библиотека „Иво Андрић“.

Од свога оснивања Институт је организовао значајне стручне скупове и научне конференције на међународном нивоу, међу којима су Његош у Андрићграду, Српска књижевност и Први светски рат, О Бранку Ћопићу, Железница, књижевност и филм, О Петру Кочићу, Мост у књижевности, историји и кинематографији, Српски језик и ћирилица данас, Иво Андрић у нашем времену, Сан о граду, Филип Вишњић - песник и беседник, Српске песникиње, Странице историје руско-српских односа у 19. и 20. веку, Живот Мехмед-паше Соколовића. Наведени скупови били су повод да се на једном месту састану уважени стручњаци и врсни познаваоци одређених области, да дају свој допринос истраживању задате теме и да размене искуства, а све у циљу развијања научноистраживачке делатности Института.

Институт такође развија издавачку делатност, објављујући научну и стручну литературу из области историје, књижевности, језика и културе: зборнике радова са научних скупова, студије савремених аутора, преводну књижевност и научне часописе. Организују се представљања издавачке делатности самог Института, али и других институција, књижевни сусрети и трибине. Своју издавачку делатност Андрићев институт представио је и на сајмовима књига у Београду, Новом Саду, Бањалуци и Москви, са којих је понео и значајне награде: Награду „Моштаница“ на сајму књига у Бања- 
луци за репринт издање часописа Иgeje и Награду за целокупну издавачку делатност за 2017. годину коју додељује Новосадски сајам.

Андрићград је већ две године заредом организатор Сајма књига, манифестације која у летњем периоду у Андрићграду окупља издавачке куће, библиотеке и љубитеље књига и књижевности. Андрићев институт, са својим Одељењима и својом Библиотеком, даје свој допринос развоју и одржавању овога пројекта кроз организацију пратећег програма Сајма књига. Пратећи програм подразумева промоције књига и издавачке делатности излагача, округле столове, трибине и други програм посвећен књигама и читању.

У Андрићевом институту се од 2014. године у континуитету организује летња школа Академија „Андрић“са циљем да младим истраживачима омогући додатно образовање кроз предавања еминентних професора. До сада су током летње школе обрађиване следеће теме: Српска књижевност и Први светски рат, Култура сећања, Културе у сусрету и Иво Андрић у нашем времену. Током трајања летње школе студенти филолошких наука свих нивоа студија својим боравком у „граду од камена“ оплемењују Андрићград и удахњују му дух младости.

\section{3. Библиотека Андрићевог института}

Библиотека „Иво Андрић“ основана је 2013. године при Андрићевом институту у Андрићграду у Вишеграду, у сврху пружања подршке активностима Института и своје колекције развија у том правцу. Највише је заступљена литература из области којима се и Институт бави: историје, књижевности, уметности. По- 
ред тога, Библиотека „Иво Андрић“ има богату збирку часописа и серијских публикација. Богата референсна збирка, коју чине одабране библиографије, речници, лексикони и енциклопедије, омогућавају корисницима бављење научно-истраживачким радом. У библиотеци се налази литература на српском, енглеском, италијанском, јапанском, немачком, шпанском, кинеском, руском, португалском, чешком и другим језицима.

У просторијама библиотеке налази се читаоница ca 15 читалачких места и са рачунарима са приступом интернету који су на располагању корисницима.

Библиотека „Иво Андрић“ пред собом има следеће циљеве:

омогућавање приступа библиотечкој и информационој грађи у научне и едукативне сврхе проширивање и допуњавање збирки и колекција у складу са потребама Андрићевог института пружање подршке доживотном учењу

пружање подршке корисницима током научно-истраживачког рада - помоћ приликом истраживања, проналажења и вредновања информација; едуковање о коришћењу електронских извора информација итд.

богаћење референсне збирке

организовање различитих културних активноСТИ

стално стручно усавршавање запосленог кадра

сарадња са другим установама науке, културе и образовања

3.1 Фонд и услуге

Тренутно се у фонду библиотеке налази око 6.000 монографских публикација, а око 5.000 публикација је стручно обрађено у систему COBISS, којем се библио- 
тека прикључила марта 2015. године. Фонд библиотеке чине и неколико десетина наслова серијских публикација, новина и часописа, које са мањом или већом редовношћу пристижу у библиотеку. Некњижна грађа, аудиовизуелна грађа, плакати, разгледнице и фотографије, такође чине део збирки Библиотеке „Иво Андрић“.

Према статистици система COBISS, учешће Библиотеке „Иво Андрић“ у систему узајамне каталогизације у 2015. години (односно од краја децембра 2015. када је запослена стекла привилегије за узајамну каталогизацију) било је 9 преузетих записа из базе СОВІВ. RS. ${ }^{1}$ Наредне, 2016. године, библиотека Андрићевог института допринела је узајамној каталогизацији са 1 креираним записом, 38 записа преузетих из базе COBISS. NET и 1555 записа преузетих из базе COBIB.RS. Тиме се број библиографских записа попео на 1602, односно библиотека је на крају 2016. године имала 1828 јединица грађе унетих у узајамни електронски каталог. ${ }^{2}$ Током 2017. године библиотека је преузела 2123 записа.

Претраживањем електронског каталога и локалне базе Андрићев институт Вишеград, долази се до следећих података које се односе на монографске публикације:

4386 наслова

4829 јединица грађе $\mathrm{e}^{3}$

У електронском каталогу забележено је 296 претрага за период од јануара 2015. до фебруара 2018. године.

1 http://vbrshome.rs.cobiss.net/o cobissu/dokumenti/STAT PRIRAST 2015 RS 1 cir.pdf

2 http://vbrshome.rs.cobiss.net/o_cobissu/dokumenti/STAT_ PRIRAST 2016 RS 1 cir.pdf

3 Подаци су ажурирани 06.06.2018. 


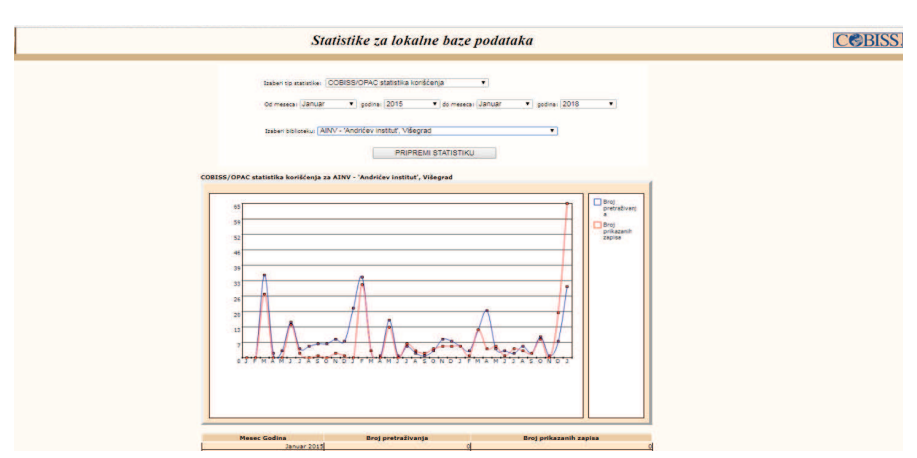

Фонд библиотеке расте поклоном установа и појединаца који су препознали значај формирања и одржавања овог јединственог библиотечко-информационог апарата у једном културном, образовном и научном комплексу као што је Андрићград. Нарочита сарадња на пољу набавке успостављена је са Народном библиотеком Србије, Народном и универзитетском библиотеком Републике Српске, Филмским центром Србије, Филолошким факултетом у Београду и другим установама.

Константан прилив у фонду током целе године чине поклони појединаца, аутора или колеционара књига, који своје књиге донирају библиотеци Андрићевог института. Неретко те донације сежу и ван граница државе, па и Балкана.

\section{2 Корисници}

Корисници библиотеке су запослени и сарадници Андрићевог института, научни радници и истраживачи чији је предмет интересовања повезан са делатностима којима се бави Андрићев институт. Библиотека је такође отворена за студенте филолошких и историјских наука, као и уметничких академија. Током већ традиционално организованих летњих школа у Андрићевом институту, библиотека је на располагању професорима и полазницима школе. 
Професори и ученици основних и средњих школа из источног дела Републике Српске такође су добродошли да користе фонд Библиотеке Андрићевог института, за потребе наставе или личног усавршавања.

\section{3 Стручно усавршавање кадра}

У циљу побошљавања услова рада, излажења у сусрет корисницима и целокупног рада на унапређењу библиотечко-информационе струке, обавеза запослених у библиотечко-информационој делатности је у сталном стручном усавршавању и унапређењу личних и професионалних вештина. Запослена у библиотеци похађала је курсеве неопходне за рад у кооперативном-онлајн библиографском систему Кобис (Уӣойреба ирроірамске оиреме COBISS3/Кайалойизација - йочейни курс) и стекла лиценцу за рад у систему узајамне каталогизације. Након завршеног курса Уйойреба йроїрамске оиреме COBISS3/Позајмица који је запослена похађала и додељених привилегија за рад, Библиотека „Иво Андрић“ маја 2017. године постала је друга библиотека у Републици Српској која је отпочела са вођењем електронске позајмице библиотечке грађе. Статистика коришћења приказана је следећом табелом.

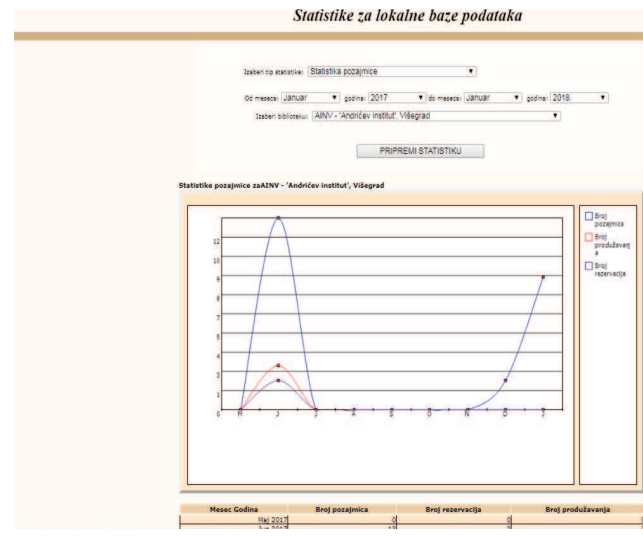

CEBISSI 
Библиотека Андрићевог Института у бити Сна о граду 179

Стручно усавршавање запослене настављено је похађањем курсева Уӣотиреба ироірамске оиреме COBISS3/Кайалоїизаиија - наиредни и Уйойреба ирроірамске оиреме COBISS3/Фонg - серијске йубликаиије. Након израде тестних записа запослена је стекла лиценце за каталогизацију некњижне грађе, серијских публикација, континуираних и интегративних извора, те се планира приступање обради те врсте грађе.

\section{4 Сарадња}

Библиотека „Иво Андрић“ успоставила је сарадњу са Народном и универзитетском библиотеком Републике Српске, на пољу аутоматизације пословања и увећавања фонда; са Народном библиотеком Србије, на пољу међубиблиотечке позајмице, стручног усавршавања запосленог и увећавања фонда; са Руским миром, на пољу достављања примерка часописа Руски мир; са Библиотеком „Иво Андрић“ из Вишеграда, Универзитетском библиотеком „Светозар Марковић“ из Београда на пољу и другим институтуцијама у земљи и иностранству.

\section{4 Закључак}

Као што људи удахњују живот мноштву зграда, тако и празним библиотечким полицама живост дају књиге. На библиотекама и библиотекарима је да учине да управо библиотека постане место на коме ће људи задовољавати своје културне, образовне и информационе потребе. Библиотеке треба да буду у току са друштвеним, технолошки и свим другим променама са којима је човек суочен, да их прате и да им се прилагођавају јер ће једино на тај начин моћи да одрже своју 
улогу информационог и културног центра локалне заједнице.

Библиотека „Иво Андрић“ тежи томе да утемељи своје место као савремено културно, образовно и информационо жариште не само Андрићграда, не само запослених у Андрићевом институту, већ свих научних радника, истраживача и заљубљеника у науку, уметност, културу. Сан о савременој, модерној, опремљеној у смислу фонда, услуга и кадра, библиотеци је сан који се у Андрићграду остварује.

Иво Андрић, којем је Андрићград и посвећен, знао је важност и значај библиотека за развој целокупног друштва. Због тога је и приход од Нобелове награде дао за развој библиотекарства у Босни и Херцеговини. Најмање што можемо да учинимо јесте да се трудимо да Библиотека која носи његово име буде таква да тај назив и оправда.

\section{Референце}

Андрићев институт http://www.andricevinstitut.org/

Кооперативни онлајн библиографски систем и сервиси СОBIB.RS http://www.rs.cobiss.net/ 